\title{
Hubungan Pola Makan Dengan Gastritis Pada Remaja Di SMK Kesehatan Napsi'ah Stabat Kabupaten Langkat
}

\section{Siskawati Amri ${ }^{1}$}

${ }^{1}$ Dosen Stikes Putra Abadi Langkat Stabat

E-mail: siskaamri28@gmail.com

\section{ABSTRACT: THE RELATIONSHIP OF EATING PATTERNS WITH GASTRITIS IN ADOLESCENTS IN NAPSI'S VOCATIONAL SCHOOL OF HEALTH, STEP STATEMENTS, LANGKAT REGENCY}

Background:Teenagers are often stuck with unhealthy eating patterns, even to the point that eating disorders can cause gastritis. Gastritis is an inflammation of the stomach mucosa that is acute and chronic. Diet is a variety of information that provides an overview of the type and amount of food eaten every day by one person and is characteristic for a particular group of people. Purpose : The purpose of this study is for the relationship between eating patterns and gastritis in adolescents at Stabat Napsi'ah Health Vocational School in 2018

Method:This type of research used in this study is an observational analytic study with a cross sectional study approach. Total population of 32 people, the sample used in this study was a total sampling of 32 people.

Result:Data analysis using chi square test with a degree of confidence $p<0.05$. Based on the results of the chi square test the relationship of eating patterns with gastritis in adolescents at Stabat Napsi'ah Health Vocational School in 2018 with a degree of significance $(a)=0.05$ and $d f=1$, the calculation results obtained are Sig (2-tailed) $0.001<(a)=0.05$, then $\mathrm{Ho}$ is rejected and $\mathrm{Ha}$ is accepted.

Conclusion: The conclusion is that there is a relationship between diet and gastritis in adolescents at Stabat Napsi'ah Health Vocational School in 2018. It is recommended that you maintain a good diet, especially at the frequency of eating with regular meals, full meals 3 times a day or by food.

Keywords : Dietary Habit, Gastritis 


\section{INTISARI: HUBUNGAN POLA MAKAN DENGAN GASTRITIS PADA REMAJA DI SMK KESEHATAN NAPSI'AH STABAT KABUPATEN LANGKAT}

Latar Belakang: Remaja sering terjebak dengan pola makan yang tidak sehat, bahkan sampai gangguan pola makan yaitu dapat menyebabkan gastritis. Gastritis adalah suatu peradangan mukosa lambung yang bersifat akut dan kronik. Pola makan adalah berbagai informasi yang memberikan gambaran mengenai macam dan jumlah bahan makanan yang dimakan setiap hari oleh satu orang dan merupakan ciri khas untuk suatu kelompok masyarakat tertentu. Tujuan : Tujuan penelitian ini untuk hubungan pola makan dengan gastritis pada remaja di SMK Kesehatan Napsi'ah Stabat tahun 2018

Jenis penelitian: Jenis penelitian yang digunakan dalam penelitian ini adalah penelitian observasional analitik dengan pendekatan studi cross sectional. Jumlah populasi sebanyak 32 orang, sampel yang digunakan dalam penelitian ini adalah total sampling sebanyak 32 orang.

Hasil : Analisa data dengan menggunakan chi square test dengan derajat kepercayaan $\mathrm{p}<0,05$. Berdasarkan hasil uji chi square hubungan pola makan dengan gastritis pada remaja di SMK Kesehatan Napsi'ah Stabat tahun 2018 dengan derajat kemaknaan $(\alpha)=0,05$ dan $\mathrm{df}=1$ diperoleh hasil perhitungan yaitu Sig (2-tailed) $0.001<$ (a) = 0,05, maka Ho ditolak dan Ha diterima.

Kesimpulan : Kesimpulannya ada hubungan antara pola makan dengan gastritis pada remaja di SMK Kesehatan Napsi'ah Stabat tahun 2018. Disarankan hendaknya menjaga pola makan dengan baik khususnya pada frekuensi makan dengan makan teratur, makanan lengkap 3 kali sehari atau makanan selingan.

Kata Kunci : Pola Makan, Gastritis

\section{PENDAHULUAN}

Pola makan yang baik pada remaja seharusnya adalah dengan makan sesuai waktunya, makan dengan nutrisi yang cukup dan seimbang, mengkonsumsi buah dan sayuran yang sehat dan bergizi, memilih makanan yang direbus bukan digoreng, mengurangi makanan cepat saji atau makanan instan dan menghindari minuman bersoda. Remaja sering terjebak dengan pola makan yang tidak sehat, bahkan sampai gangguan pola makan yaitu dapat menyebabkan gastritis. Gastritis merupakan suatu peradangan mukosa lambung yang paling sering terjadi akibat ketidakteraturan makan. Gastritis biasanya diawali oleh pola makan yang tidak teratur sehingga lambung menjadi sensitif bila asam lambung meningkat. Pola makan adalah berbagai informasi yang memberikan gambaran macam dan model bahan makanan yang dikonsumsi setiap hari.Pola makan terdiri dari jenis makanan, frekuensi makan, jadwal makan dan porsi makan.Pola makan yang baik dan teratur merupakan satu diantara penatalaksanaan gastritis. Pola makan remaja yang buruk adalah seperti jadwal makan yang tidak teratur, mengkonsumsi makanan yang memiliki nilai gizi rendah dan meningkatkan produksi asam lambung, serta jumlah makanan yang terlalu banyak dan juga terlalu sedikit (Hidayah, 2014).

Badan penelitian kesehatan dunia WHO mengadakan tinjauan terhadap delapan Negara dunia dan mendapatkan beberapa hasil presentase angka kejadian gastritis di dunia. Dimulai dari 
Negara yang kejadian gastritisnya paling tinggi yaitu Amerika dengan presentase mencapai $47 \%$ kemudian di ikuti oleh India dengan presentase mencapai $43 \%$, lalu dibeberapa negara lainnya seperti Inggris 22\%, China 31\%, Jepang 14,5\%, Kanada 35\%, Perancis 29,5\% dan Indonesia 40,85\%. Angka kejadian gastritis pada beberapa daerah di Indonesia cukup tinggi dengan prevalensi 274,396 kasus dari 238,452,952 jiwa penduduk. Gastritis biasanya anggap sebagai suatu hal yang remeh namun gastritis merupakan awal dari sebuah penyakit yang dapat menyusahkan kita (Handayani \& Thomy, 2018)

Badan penelitian kesehatan dunia WHO mengadakan tinjauan terhadap delapan Negara dunia dan mendapatkan beberapa hasil presentase angka kejadian gastritis di dunia. Dimulai dari Negara yang kejadian gastritisnya paling tinggi yaitu Amerika dengan presentase mencapai $47 \%$ kemudian di ikuti oleh India dengan presentase mencapai $43 \%$, lalu dibeberapa negara lainnya seperti Inggris 22\%, China 31\%, Jepang 14,5\%, Kanada 35\%, Perancis 29,5\% dan Indonesia 40,85\%. Angka kejadian gastritis pada beberapa daerah di Indonesia cukup tinggi dengan prevalensi 274,396 kasus dari $238,452,952$ jiwa penduduk. Gastritis biasanya anggap sebagai suatu hal yang remeh namun gastritis merupakan awal dari sebuah penyakit yang dapat menyusahkan kita (Handayani \& Thomy, 2018).

Penderita gastritis (Dyspepsia atau penyakit maag), banyak dijumpai di kalangan masyarakat umum. Gastritis (pembengkakan dari lapisan mukosa dinding lambung) bisa disebabkan, antara lain, oleh iritasi, infeksi, dan atropi mukosa lambung. Bakteri Helicibacter pylori, dikenal sebagai ancaman utama lambung dan juga berbagai jenis usus. Suatu penemuan oleh National Institute of Health (NIH) Amerika Serikat, yaitu adanya asosiasi yang kuat antara H.pylori dengan penyakit ulkus (ulser) pada lambung maupun usus (Misnadiarly, 2018).

Gastritis merupakan peradangan yang mengenal mukosa lambung.perdangan ini dapat mengakibatkan pembengkakan mukosa lambung sampai terlepasnya epitel akan gangguan saluran pencernaan. Pelepasan epitel akan merangsang timbulnya proses inflamasi pada lambung (Ardian, Adwan 2017)

$$
\text { Masalah kesehatan remaja }
$$
merupakan suatu hal yang makin menonjol pada saat ini, dimana terdapat kecenderungan peningkatan yang pesat dari penyalahgunaan obat, pergaulan bebas dan perubahan pola makan (Pratiwi, 2013)

Berdasarkan studi pendahuluan yang telah dilakukan oleh penulis di SMK Kesehatan Napsi'ah bahwasannya sering siswa absen tidak masuk sekolah dikarenakan sakit perut yang dideritanya oleh hal ini disebabkan karena kebiasaan pola makan yang kurang baik dan mengkonsumsi makanan yang justru dapat menyebabkan iritasi pada lambung. Hal ini menjadi dasar keterkaitan penulis melakukan penelitian tentang pola makan dengan gastritis pada remaja di SMK Kesehatan Napsi'ah Stabat tahun 2018

\section{METODOLOGI PENELITIAN}

Jenis Penelitian ini adalah merupakan penelitian survei analitik dengan pendekatan Cross sectional untuk mengetahui adanya hubungan pola makan dengan gastritis pada 
$\begin{array}{lllll}\text { remaja. Dengan memberikan } & \text { Total } & 32 & 100.0\end{array}$

kuesioner sebanyak 20 pertanyaan. Kuesioner terlebih dahulu telah dilakukan uji validitas kepada 15 responden. Semula kuesioner yang buat sebanyak 20 dan semua dinyatakan valid Valid. Penelitian ini telah disetujui pihak LPPM dengan No Surat : 038/LPPM-STIKes Pal/X/2018. Populasi yang diambil dalam penelitian ini adalah remaja di SMK Kesehatan Napsi'ah kelas VIII sebanyak 32 orang. Tehnik pengambilan sampel menggunakan total sampling No Gastritis Jumlah Persentase(\%) yaitu pengambilan seluruh dari populasi sebanyak 32 orang. Jenis data yang diperoleh dalam penelitian ini adalah data primēr diperoleh dari hasil wawancara dengan menggunakan kuesioner. Data yang sudah didapatkan kemudian dilakukan analisis data univariat dan bivariat dalam bentuk distribusi frekuensi dan untuk mencari hubungan antara 2 variabel menggunakan UJI SPSS dan diperoleh hasil uji chi-square dengan tingkat kepercayaan 95\% dan disajikan dalam bentuk table dan narasi

\section{HASIL PENELITIAN}

Analisis Univariat

1. Pola Makan

Tabel 1

Distribusi Respoden Pola Makan di

SMK Kesehatan Napsi'ah Stabat Kabupaten Langkat

\begin{tabular}{cccc}
\hline No & $\begin{array}{l}\text { Pola } \\
\text { Makan }\end{array}$ & Jumlah & $\begin{array}{c}\text { Persentase } \\
\text { (\%) }\end{array}$ \\
\hline 1 & Teratur & 14 & 43.8 \\
\hline 2 & Tidak & 18 & 56.2 \\
& Teratur & & \\
\hline
\end{tabular}

Siskawati Amri

${ }^{1}$ Dosen Stikes Putra Abadi Langkat Stabat

E-mail: siskaamri28@gmail.com
Berdasarkan tabel 1 diketahui bahwa dari 32 responden, mayoritas pola makan tidak teratur berjumlah 18 orang (56.2\%) dan minoritas pola makan teratur berjumlah 14 orang (43.8\%).

\section{Gastritis}

Tabel 2

Distribusi Respoden Pola Makan

di SMK Kesehatan Napsi'ah Stabat Kabupaten Langkat

$\begin{array}{cccc}1 & \text { Terjadi } & 17 & 53.1 \\ 2 & \text { Tidak } & 15 & 46.9\end{array}$

Terjadi

$\begin{array}{lll}\text { Total } & 32 & 100.0\end{array}$

Berdasarkan tabel 2 diketahui bahwa dari 32 responden, mayoritas terkena terjadi gastritis berjumlah 17 orang (53.1\%) dan tidak terjadi gastritis berjumlah 15 orang (46.9\%).

\section{Analisis Bivariat}

Analisis bivariat dimaksudkan untuk menganalisis hubungan variabel independen (pola makan) dengan dilihat dengan menggunakan uji chi square pada taraf kepercayaan $95 \%$.

Berdasarkan tabel 3 diketahui bahwa dari 32 responden mayoritas tidak terjadi gastritis dengan pola makan yang teratur sebanyak 13 orang $(72.2 \%)$, dan mayoritas responden terjadi gastritis dengan pola makan yang tidak teratur yaitu sebanyak 12 orang $(85.7 \%)$

Berdasarkan hasil uji chi square hubungan pola makan dengan gastritis Pada Remaja Putri Di SMK Kesehatan Napsi'ah Stabat Tahun 2018 dengan derajat kemaknaan $(\alpha)=0,05$ dan $d f=1$ diperoleh hasil perhitungan yaitu Sig (2variabel dependen (gastritis) yang 
tailed) $0.001<(a)=0,05$, maka Ho ditolak dan $\mathrm{Ha}$ diterima. Kesimpulannya ada hubungan antara pola makan dengan gastritis pada remaja di SMK Kesehatan Napsi'ah Stabat Tahun 2018.

\section{PEMBAHASAN \\ Analisa Univariat Pola Makan}

Berdasarkan hasil penelitian dapat diketahui bahwa dari 32 responden, mayoritas pola makan tidak baik berjumlah 18 orang (56.2\%) dan minoritas pola makan baik berjumlah 14 orang (43.8\%).

Menurut Potter \& Perry (2015) pola makan yang tidak baik dan tidak teratur dapat meningkatkan asam lambung sehingga lambung menjadi sensitif dan menyebabkan terjadinya gatritis. Hal ini sebagaimana yang disampaikan oleh Restianti (2016) bahwa orang yang memiliki pola makan tidak teratur mudah terserang penyakit gastritis. Sebab pada saat perut harus di isi, tapi dibiarkan kosong atau ditunda pengisiannya maka asam lambung akan mencerna lapisan mukosa lambung, sehingga timbul rasa nyeri. Pola makan tidak teratur akan membuat lambung sulit beradaptasi. Jika hal tersebut berlangsung lama, produksi asam lambung akan berlebih sehingga dapat mengiritasi dinding mukosa lambung. Selain keluarnya asam lambung, kontraksi lapar juga akan menghasilkan gerakan kontraksi yang kuat. Kontraksi ini sering terjadi bila lambung dalam kondisi kosong dalam waktu yang lama. Kontraksi ini biasanya merupakan kontraksi peristaltic ritmik yang mungkin merupakan gelombang pencampuran tambahan pada korpus lambung.

Gelombang ini akan menjadi sangat kuat sekali. Dinding lambung satu sama lain saling bergabung dan menimbulkan kontraksi yang berlangsung terus menerus selama dua sampai tiga menit. Kontraksi lapar biasanya paling kuat pada orang muda sehat dan akan bertambah kuat pada keadaaan kadar gula darah rendah (Guyton \& Hall, 2016).

Menurut Baliwati (2014) masa remaja adalah masa mencari identitas diri, adanya keinginan untuk dapat diterima oleh teman sebaya dan mulai tertarik oleh lawan jenis menyebabkan remaja, termasuk pemilihan bahan makanan dan frekuensi makan. Remaja takut merasa gemuk sehingga remaja menghindarii sarapan dan makan siang atau hanya makan satu hari satu kali.

Asumsi peneliti kebiasaan pola makan yang tidak teratur mengakibatkan terjadinya peningkatan asam pada lambung sehingga mukosa pada lambung akan terkikis dan mengakibatkan sakit, pola makan yang baik akan terhindar dari penyakit gastritis.

\section{Gastritis}

Berdasarkan hasil penelitian dapat diketahui bahwa dari 32 responden, mayoritas terkena terjadi gastritis berjumlah 17 orang (53.1\%) dan tidak terjadi gastritis berjumlah 15 orang (46.9\%)

Penelitian Pratiwi (2014) menyakatan bahwa asam lambung dapat terkontrol meskipun frekuensi makan kurang dari 3 kali dalam sehari, apabila diselingi dengan mengkonsumsi makanan ringan yang tidak mengiritasi lambung. Menurut Sediaoetama dalam Rifqiyatunnasiyah, (2017) jenis makanan yang dapat mengiritasi diantaranya adalah makanan pedas, zatzat korosif seperti cuka dan lada. Jenis makanan tersebut dapat menyebabkan 
kerusakan mukosa gaster dan tidak jarang juga menimbulkan luka pada dinding lambung.

Asumsi peneliti pengamatan yang dilakukan peneliti responden sering makan tidak teratur, porsi makan yang terkadang sedikit dan terkadang banyak, dan jenis makanan yang cenderung di kosumsi mengakibatkan gastritis.

\section{Analisa Bivariat}

Hubungan Antara Pola Makan Dengan Gastritis Pada Remaja

Berdasarkan hasil uji chi square hubungan pola makan dengan gastritis Pada Remaja di SMK Kesehatan Napsi'ah Stabat tahun 2018 dengan derajat kemaknaan $(\mathrm{a})=0,05 \mathrm{dan} \mathrm{df}=1$ diperoleh hasil perhitungan yaitu Sig (2-tailed) 0.001> (a) $=0,05$, maka Ho ditolakdan Ha diterima. Kesimpulannya ada hubungan antara pola makan dengan gastritis remaja di SMK Kesehatan Napsi'ah Stabat

Dari hasil penelitian ini menunjukkan adanya hubungan pola makan dengan kejadian gastritis, dimana responden dengan pola makan yang tidak baik berisiko terjadi gastritis begitu juga sebaliknya. Hasil penelitian ini sejalan dengan penelitian yang dilakukan oleh Onibala (2014) bahwa pola akan merupakan factor terjadinya gastritis yang menyatakan bahwa ada hubungan antara pola makan dengan gastritis dengan $\mathrm{p}$ value $=$ 0.009

Namun dalam hasil penelitian ini juga didapatkan responden pola makan yang tidak baik, mayoritas remaja mengalami gastritis kronis yaitu sebanyak 13 orang (72.2\%). Hal ini menunjukkan bahwa kejadian gastritis tidak hanya disebabkan oleh pola makan, akan tetapi ada beberapa faktor lain yang mempengaruhi kejadian gastritis pada siswa.

Menurut Mustafa, Menon, Muiandy, Fredie, Sein, \&Fariz (2015) factor risiko gastritis yang umum terjadi meliputi stres, alkohol, merokok, dan kokain. Selviana (2015) lebih lanjut menjelaskan bahwa stres yang berkepanjangan merupakan salah satu factor pemicu terjadinya gastritis karena mengakibatkan peningkatan produksi asam lambung. Kadar asam lambung yang meningkat akan menimbulkan ketidaknyamanan pada lambung. Gastritis juga sering dihubungkan dengan keadaan psikologis seseorang.

$$
\text { Penelitian Pratiwi (2014) }
$$

menyakatan bahwa asam lambung dapat terkontrol meskipun frekuensi makan kurang dari 3 kali dalam sehari, apabila diselingi dengan mengkonsumsi makanan ringan yang tidak mengiritasi lambung. Menurut dalam Rifqiyatun nasiyah, (2017) jenis makanan yang dapat mengiritasi diantaranya adalah makanan pedas, zat-zat korosif seperti cuka dan lada. Jenis makanan tersebut dapat menyebabkan kerusakan mukosa gaster dan tidak jarang juga menimbulkan luka pada dinding lambung.

\section{KESIMPULAN}

Berdasarkan hasil penelitian dan pembahasan yang telah diuraikan sebelumnya maka diperoleh kesimpulan sebagai berikut :Dari 32 responden, mayoritas pola makan tidak baik berjumlah 18 orang (56.2\%) dan minoritas pola makan baik berjumlah 14 orang (43.8\%), Dari 32 responden, mayoritas terjadi gastritis berjumlah 17 orang $(53.1 \%)$ dan tidak terjadi gastritis berjumlah 15 orang (46.9\%) dan Ada hubungan antara pola makan dengan gastritis pada remaja di SMK Kesehatan Napsi'ah Stabat tahun 2018. dengan derajat kemaknaan $(\alpha)=0,05 \mathrm{dan} d f=1$ 
diperoleh hasil perhitungan yaitu Sig (2-tailed) $0.001<(a)=0,05$, maka Ho ditolak dan Ha diterima.

\section{SARAN}

Untuk siswa, diharapkan dapat melakukan kebiasaan hidup sehat dengan mengatur pola makan yang sesuai juga memperhatikan jenis makanan yang dikonsumsi dengan menghindari jenis makanan yang menjadikan faktor resiko

\section{DAFTAR PUSTAKA}

Arikunto,

(2016).ProsedurPenelitian:

Suatu Pendekatan Praktik. Jakarta: RinekaCipta.

Ardian Ratu R dan G. Made Adwan, (2017). Penyakit Hati, Lambung, Usus dan Ambeien. Yogyakarta: Nuhamedika.

Atikah Proverawat dan Erni Kusuma Wati, (2017). Ilmu Gizi Untuk Keperawatan \& Gizi Kesehatan. Yogyakarta: Nuhamedika.

Baliwati, Y. F. (2015). Pengantar Pangan Dan Gizi. Jakarta: Penebar Swadaya.

Guyton, A. C. \& Hall, J. E. (2016). Buku Ajar Fisiologi Kedokteran. Singapura: Elsevier.

Hidayah, (2014). Kesalahankesalahan Pola Makan Pemicu Seabrek Penyakit Mematikan. Jogjakarta : BukuBiru.

Hidayati, R., Soviana. E., \& Widyaningsih, E. N. (2016). Perbedaan Pengetahuan Gizi Dan Kebugaran Jasmani Pada terjadinya gastritis, juga pengendalian emosi dalam mengatasi stress psikologis.

Untuk guru, diharapkan mengoptimalkan dan menambah peran guru pembimbing dalam melaksanakan bimbingan dan konselingnya dengan cara memfasilitasi siswa yang bermasalah kesehatan untuk melakukan penyuluhan dan bimbingan, tidak hanya memberikan bimbingan dibidang akademiknya.

Remaja Yang Overweught Dan Non Overweight Di SMK Batik 2 Surakarta. urnalKesehatan. ISSN 1979-7621.Vol. 1, No. 2 Desember 2016.

Ida Mardalena, (2017). Asuhan Keperawatan pasien Dengan Gangguan Sistem Pencernaan. Yogyakarta. PustakaBaru Press.

Marmi, (2018). Gizi dalam Kesehatan Reproduksi. Yogyakarta: Pustaka Pelajar.

Misnadiarly, (2018). Mengenal Penyakit Organ Cerna. Jakarta Pustaka Obor Populer.

Mardalena, (2015). IlmuGizi. Yogyakarta: Nuhamedika.

Marmi, (2018). Aspek Dasar Kependidikan. Jakarta: Bina Aksara.

Mutmainah Handayani, Tigor Abdurrahman Thomy (2018). Hubungan Frekuensi, Jenis Dan Porsi Makan Dengan Kejadian Gastritis Pada Remaja. Jurnal Kesehatan Saelmakers Perdana ISSN 2615-6571 (Print), ISSN 26156563 (Online) Tersedia online di 
http://ojs.ukmc.ac.id/index. $\mathrm{php} / \mathrm{JOH}$.

Mustafa, M., Menon, J., Muiandy, RK.,Fredie R., Sein MM., Fariz, A. (2015). Risk Factors, Diagnosis, and Management of Peptic ulcer Disease. IOSR Journal of Dental and Medical Sciences (IOSR-JDMS).e-ISSN: 22790853, pISSN: 22790861. Volume 14, Issue 7 Ver. VIII (July. 2015), PP 40-46.

Notoatmodjo, S. (2016) .Metodologi Penelitian Kesehatan. Jakarta: RinekaCipta.

Nursalam.(2016). Metodologi Penelitian IImu Keperawatan: Pendekatan Praktis : Jakarta : Salemba Medika.

Onibala, F., Angkow, J., \& Robot F. (2014). Faktor-Faktor Yang Berhubungan Dengan Kejadian Gastritis di Wilayah Kerja Puskesmas Bahu Kota Manado. Program Studi IImu Keperawatan Fakultas Kedokteran. Universitas Sam Ratulangi Manado.

Restianti, H. (2016). Menerapkan Budaya Hidup Sehat: Pola Makan dan Keseimbangan Gizi. Bandung: PuriPustaka.

Rifqiyatunnasiyah, (2017). Hubungan
Pola Makan Dengan Kejadian Gastritis Pada Santri Di Pondok Pesantren Al-Mukmin Sukoharjo. Fakultas Ilmu Kesehatan Universitas Muhammadiyah Surakarta.

Salahuddin. Iwan. (2018), Hubungan Pola Makan Dengan Gastritis Pada Remaja Di Sekolah Menengah Kejuruan Ybkp3 Garut. Jurnal Kesehatan Bakti Tunas Husada Volume 18 Nomor $1 \quad$ Februari 2018Sulistyoningsih, (2017). Gizi Untuk Kesehatan Ibu dan Anak. Yogyakarta: Graha Ilmu.

Sudjana, (2014). Metode Statistik. Jakarta: Rineka Cipta.

Selviana, B.Y. (2015). Effect of Coffee and Stress With The Incidence of Gastritis. J MAJORITY, Volume 4 Nomer 1.

Pratiwi, (2014). Hubungan Pola Makan dengan Gastritis pada Remaja di Pondok Pesantren Daar El-Qolam Gintung Jayanti Tangerang, Universitas Islam Negeri Syarif Hidayatullah, Fakultas Kedokteran dan IImu Kesehatan, Jakarta, (Skripsi) .

Potter, P.A., \& Perry, A.G. (2015). Fundamental Keperawatan, Edisi 7 Buku 3. Singapura: Elsevier. 